\title{
Micronutrient status in soils of chilli grown areas of UKP command area, Karnataka
}

SHIVAKUMAR, K.M. AND M.S. NAGARAJA

Received : 05.08.2016; Revised : 29.10.2016; Accepted : 22.11.2016

MEMBERS OF RESEARCH FORUM:

Corresponding author : SHIVAKUMAR K.M., Department

of Soil Science and Agricultural

Chemistry, College of Horticulture,

Sirsi, UTTARA KANNADA

(KARNATAKA) INDIA

Email: shivakumaruhs@gmail.com

\section{Co-authors :}

M.S. NAGARAJA, Department of Soil Science and Agricultural

Chemistry, College of Horticulture,

University of Horticultural Sciences, BAGALKOT (KARNATAKA) INDIA

\section{Summary}

An investigation was carried out to study the micronutrients status in soils of chilli grown areas of UKP command at College of Agriculture, Raichur, during the year 2006-07. The concentration of iron and manganese in soil samples collected before the crop season ranged from 3.95 to $4.95 \mathrm{ppm}$ and 23.03 to $25.87 \mathrm{ppm}$, respectively and their concentration increased after the harvest of the crop. Similarly, the soil samples of experimental sites recorded moderate levels of micronutrients did not vary significantly but the soil supplemented with organic manures (Category-2 and category-4) recorded higher levels of micronutrients compared to no organic manure added chilli cultivated soil samples (Category-3).

Key words : Nutrient management practices, DTPA extractable micronutrients, Command area, Chilli, Soil fertility

How to cite this article : Shivakumar, K.M. and Nagaraja, M.S. (2016).Micronutrient status in soils of chilli grown areas of UKP command area, Karnataka. Asian J. Soil Sci., 11 (2) : 337-340 : DOI : 10.15740/ HAS/AJSS/11.2/337-340. 